\title{
Article \\ Cross-Cultural Analysis of the Consumer Profile of Hunting Tourism and Trophy Hunting from Tradition to Protected Areas: Study Case on Romania and Spain
}

\author{
Flavia Dana Oltean and Manuela Rozalia Gabor*(D)
}

check for updates

Citation: Oltean, F.D.; Gabor, M.R. Cross-Cultural Analysis of the Consumer Profile of Hunting Tourism and Trophy Hunting from Tradition to Protected Areas: Study Case on Romania and Spain. Land 2021, 10, 1218. https://doi.org/ 10.3390/land10111218

Academic Editors: María de la Cruz del Río-Rama,

José Álvarez-García,

Amador Durán-Sánchez and Pedro Cuesta-Valiño

Received: 23 October 2021

Accepted: 8 November 2021

Published: 10 November 2021

Publisher's Note: MDPI stays neutral with regard to jurisdictional claims in published maps and institutional affiliations.

Copyright: (c) 2021 by the authors. Licensee MDPI, Basel, Switzerland. This article is an open access article distributed under the terms and conditions of the Creative Commons Attribution (CC BY) license (https:// creativecommons.org/licenses/by/ $4.0 /)$.
ED1 Department of Economic Sciences, Faculty of Economics and Law, "G.E. Palade" University of Medicine, Pharmacy, Sciences and Technologies of Târgu Mures, 540142 Târgu Mures, Romania; flavia.oltean@umfst.ro

* Correspondence: manuela.gabor@umfst.ro or rozalia_gabor@yahoo.com

\begin{abstract}
Hunting has major importance from many perspectives: As a product of leisure and recreation, as a tool for conservation and wildlife management, as the main economic activity in rural areas, or as a cultural heritage and traditional activity for countries around the world, especially for countries in Europe and Africa. Therefore, this research fills a gap in the literature and offers a cross-cultural opinion and perceptions of 198 hunters from Romania and Spain. The aim of the paper is to analyze the perceptions and opinions of hunters regarding hunting tourism through an online self-administrated questionnaire by convenience sampling using hunters associations from these countries. Among the values that identify hunting as an activity, hunters highlight the human values (friendship, company, ethics), ecological values (love of nature associated with hunting as a tool to understand and enjoy the natural environment), and social values (resources generated, hobby, effort). The respondents can self-criticize some components and aspects of hunting groups. Hunters believe that the future of this sector is moving towards commercial hunting, associated with purchasing power to ensure results. Regardless of the nationality of the hunters, their values related to this sector are similar.
\end{abstract}

Keywords: hunting tourism; Romania; Spain; hunters; quantitative analysis; values; protected area; traditions

\section{Introduction}

Hunting is one of the most important activities of the primary sector [1] whose evolution-from the primitive character of the activity as a surviving purpose-until now has undergone remarkable technical, organizational, social, and economic transformations.

Hunting tourism is defined as [2] "an organized paid trip aimed on satisfying the needs of consumers (hunters) in service or extreme, sports and recreational or cognitive character in the process of their staying in the natural habitat of hunting animals". Hunting tourists are those hunters who travel outside their usual hunting area [3].

Currently, hunting can be analyzed from four perspectives:

- As a product of leisure and recreative [4], namely hunting tourism, due to the increase in experience in practicing this information in recent decades;

- $\quad$ as the use and conservation of natural spaces to keep the animal population controlled and ordered the number of specimens to support the natural balance, intersected with wildlife regulation [5], the commodification of wildlife experiences [6], and wildlife management for sustainable hunting [7];

- $\quad$ as an economic activity by setting up an income supplement in hunting areas, a market hunting being created as a new tourism economy [5] especially in rural areas [8], jobcreating activity [1,9], and sometimes with the purpose of reducing poverty [10];

- $\quad$ as cultural heritage $[9,11-13]$ and traditional activity [14]. 
Trophy hunting and hunting tourism have socioeconomic and ecological benefits [15-18] at the local and regional levels [9,19]. Moreover, as a primeval human activity, hunting has an increasing effect on the conservation of nature and positive economic effects through hunting tourism [20]. Trophy hunting tourism plays an important and often controversial role in wildlife conservation and community livelihood especially for African countries [8,21-24]. For example, the annual amount spent by trophy hunters in South Africa is USD 250 million and contributes more than USD 341 million to the South African economy, and supports more than 17,000 employment opportunities [8]. Practically, the core of the South Africa tourism industry is based on wildlife tourism and hunting is one of the major income generators for product owners [25-27].

Hunting has also been the subject of worldwide criticism in recent years, both moral and economic value of hunting tourism business [6] or regarding the negative impact among the locals $[10,21]$ being researched by academics. Both ethically, as well as biodiversity conservation, or economically [28], it is rightly called into question that hunting is an activity based exclusively on the appetite of a limited group of people who enjoy the mere fact of killing animals. This led to a logical and progressive social disappointment with an activity involving the free and unjustified death of wild and domestic animals [29]. The hunting sector has reacted to this by creating a lobby with ramifications in political and economic power that desperately seeks the survival of the hunt by creating an image that hunting is a sustainable development factor [30], a tool for population management, and an essential economic activity for the rural environment [31]. Moreover, in most African countries, the prohibition of hunting has a negative economic impact on the livelihoods and rural community [29,32]. Furthermore, tourism and hunting both generate substantial revenues for communities and private operators in Africa [33]. On the other hand, another important aspect is pointed out: as traditional international trophy hunting destinations are becoming less accessible due to hunting restrictions and regulations, new destinations are entering the scene, such as the Republic of Kyrgyzstan [34].

The last available statistical evolution of the number of hunters in Europe is presented in Figure 1. France is in first place with 1,313,000 hunters, secondly Spain with 980,000 hunters, and Romania with 60,000 hunters in 2017.

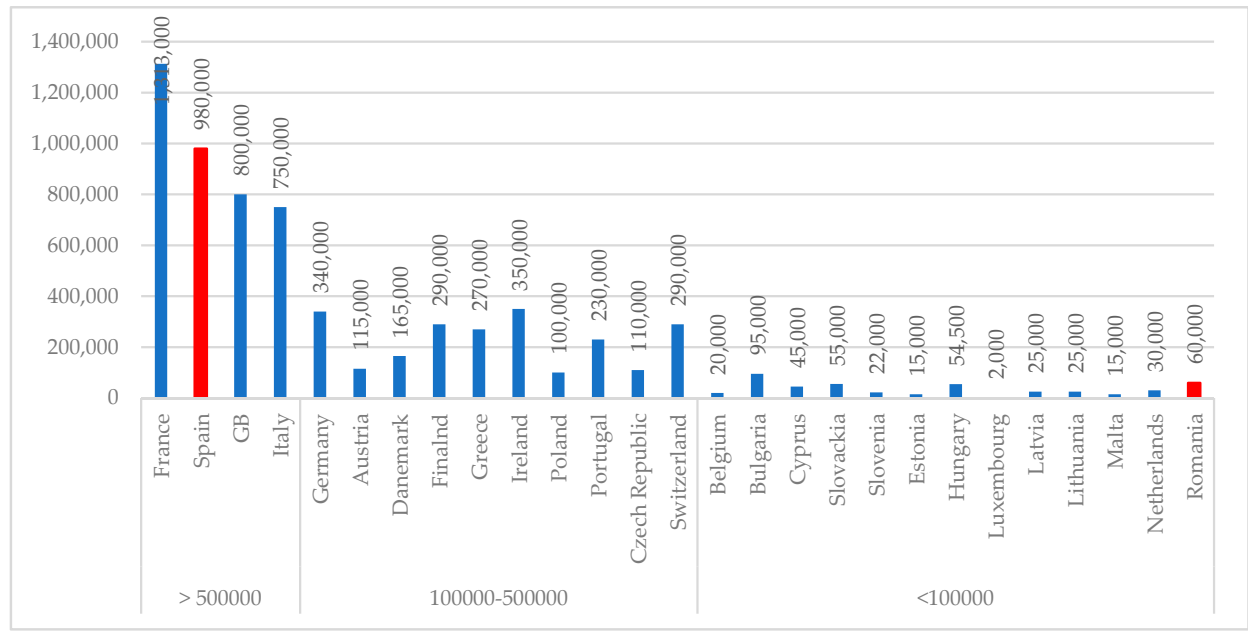

Figure 1. Number of hunters in Europe in 2017.

For Romanian rural communities, the role of hunting tourism must be to preserve the sustainability of fauna habitats [35,36] to develop the rural tourism market [37] or rural communities [38] and promote sustainable nature-based tourism through conforming hunting tourism to modern tendencies which involve responsible traveling to natural areas [39]. Moreover, there are European countries, such as the Czech Republic, that promote and sustain hunting tourism as a modern product for the country's development, especially for rural regions [40,41] or, for Croatia, to form a hunting tourism brand [42]. 
In general, society's, stakeholders, and local household [19] views on hunting, the economic and environmental aspects [43] have been studied in more detail than the opinions of its own hunters and neglect a parameter as important as demand [43]. Moreover, there are no research results regarding Romania or at the national level [1] but for:

- Other European countries, such as Ukraine [2], Spain [3,44], Serbia [37,45,46], Croatia [20,42,47-49], Sweden [6,9,50], Norway [4,12,51], Czech Republic [40,41], and Finland [38,52];

- African countries such as Namibia [17,21,23,26,28-30,33,53,54], Ghana [55], Botswana [32,56,57], Zimbabwe [15,58], Senegal [28], and Ethiopia [16,59];

- other countries, such as Pakistan [19], Canada [5].

Therefore, this research fills a gap in the literature and offers a cross-cultural opinion and perceptions of hunters from two European countries, Romania and Spain, both with a traditional activity of hunting and trophy hunting. The aim of the paper is to analyze the perceptions and opinions of hunters from Romania and Spain regarding hunting tourism through an online self-administrated questionnaire (in Romanian language and Spanish language) by convenience sampling using hunters associations from these countries. The objectives of this research are as follows:

- To find the values of the hunting for the Romanian and Spanish hunters;

- to identify the preferences of the subjects regarding the hunting method and the type of hunted species;

- to identify the annual budget allocated by the hunters from these countries;

- to study the opinion of hunters regarding the future of this activity and the opinion of the current society about hunting from their perspectives;

- to establish similarities and differences of the Romanian and Spanish hunters by using statistical methods (the non-parametrical correlations, the Spearman coefficient ant the chi-square bivariate test).

The research results show that the values that the hunters exhibit the most are the human (friendship, companionship, ethics), ecological (love of nature, associated with hunting as a tool for understanding and enjoying the natural environment), and social (resources generated, hobby, effort) aspects of hunting. A majority of those interviewed consider that society has a negative view of hunting. In the future the traditional hunting must be adapted to the present times, keeping its the commercial component if it want to subsist. Self-criticism carried out by the hunters themselves, invites us to think that the existence of future meeting points, not exempt from debate, with anti-hunting collectives, being the appreciation of nature and the interest in maintaining it, is the basis of the future of hunting.

\section{Materials and Methods}

According to the aim and the objectives of the research, we applied an online selfadministrated questionnaire [3,8,9,16,44,52]. Data were collected from 15 April to 20 May 2021. The questionnaires were distributed in Romania and Spain, in the native language of the respondents through convenience sampling $[55,58,60]$ on the hunter's associations and groups from Romania and Spain [8]. By applying the questionnaire, an analysis was made of some important aspects: society's perception of hunters, people who harm hunters, significant values in the hunting world, and in which direction this activity is directed, to make a comparison between the two samples analyzed and to know the economic and environmental potential of this activity. The questionnaire has 23 questions structured in three sections according to the research objectives:

- The first five questions regarding the hunting data;

- eight questions about the position of hunters in society and the values of hunting as an activity from the hunter's point of view;

- the last ten questions refer to socio-demographic data and hunting preferences for describing the hunter profile. 
The research sample has 298 respondents-158 Romanian and 140 Spanish hunters. The comparative structure of the samples' socio-demographic characteristics is presented in Table 1. The results show that only for Spain the sample has both females and males, all the 158 Romanian hunters are males. The average age for both nationalities is 38 years old. Moreover, the distribution of the samples according to the occupation status is approximately the same for Romania and Spain.

Table 1. Sample description-general socio-demographic data.

\begin{tabular}{lcccc}
\hline \multirow{2}{*}{ Characteristics } & \multicolumn{2}{c}{ Absolute Frequencies } & \multicolumn{2}{c}{ Relative Frequencies } \\
\cline { 2 - 5 } & $\begin{array}{c}\text { Romania } \\
(n=\mathbf{1 5 8})\end{array}$ & $\begin{array}{c}\text { Spain } \\
(\boldsymbol{n}=\mathbf{1 4 0 )})\end{array}$ & $\begin{array}{c}\text { Romania } \\
(\boldsymbol{n}=\mathbf{1 5 8})\end{array}$ & $\begin{array}{c}\text { Spain } \\
(\boldsymbol{n}=\mathbf{1 4 0})\end{array}$ \\
\hline Gender & & & & \\
$\quad$ Female & 0 & 11 & $0 \%$ & $8 \%$ \\
Male & 158 & 129 & $100 \%$ & $92 \%$ \\
\hline Age & & & & \\
Under 30 years old & 36 & 34 & $23 \%$ & $24 \%$ \\
31-40 years old & 54 & 47 & $34 \%$ & $34 \%$ \\
41-50 years old & 41 & 42 & $26 \%$ & $30 \%$ \\
Over 50 years old & 27 & 17 & $17 \%$ & $12 \%$ \\
\hline Occupational status & & & & \\
Business owner & 17 & 18 & $11 \%$ & $13 \%$ \\
Freelance & 16 & 11 & $10 \%$ & $8 \%$ \\
Manager & 14 & 12 & $9 \%$ & $9 \%$ \\
Employed with higher education & 74 & 65 & $47 \%$ & $46 \%$ \\
Employed with secondary education & 29 & 26 & $18 \%$ & $19 \%$ \\
Unemployed & 1 & 0 & $1 \%$ & $0 \%$ \\
Retired & 7 & 8 & $4 \%$ & $6 \%$ \\
\hline Source: own calculations. & & & &
\end{tabular}

Source: own calculations.

Regarding the place of origin of the Romanian and Spanish hunters, the distribution is presented in Figure 2a,b. For both countries, most hunters are from the country capital but cover an important geographical area of each country.

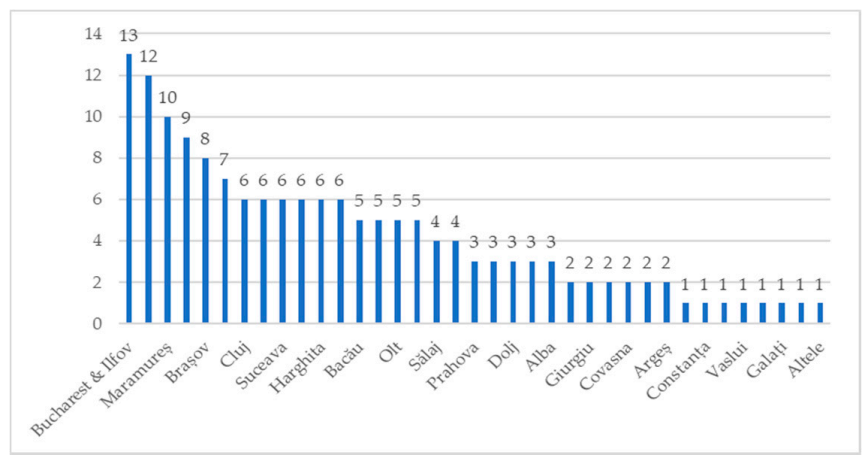

(a)

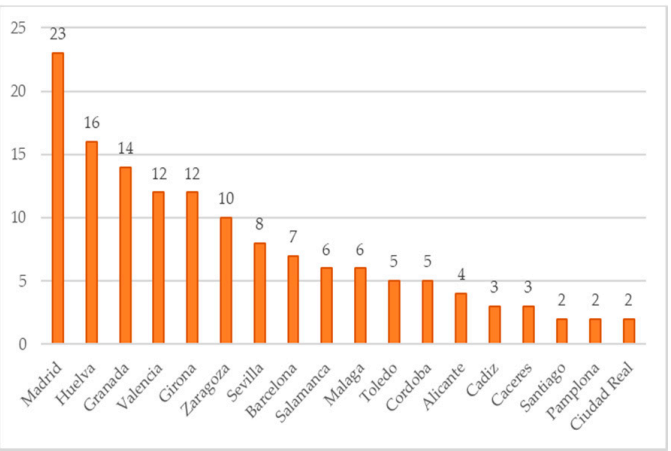

(b)

Figure 2. (a) Place of origin of Romanian hunters; (b) place of origin of Spanish hunters.

To emphasis the relation between hunters' profiles (results are presented in Section 3.1), hunting data (results are presented in Section 3.2, the position of hunters in society, and the values of hunting as activity (results are presented in Section 3.3), we applied nonparametrical statistical methods [43] due of the categorical data of the research, respectively:

- The Spearman correlations coefficient

- The chi-square bivariate test [58] inside of each group, respectively, for Romania and Spain. These results are presented in Section 3.4. 
For the statistical analysis of the collected data, the SPSS 23.0 (licensed) software was used and Microsoft Excel for graphical representations. In the Results section of the article, all the research results are presented comparatively, not separately, for Romania and Spain.

\section{Results}

\subsection{The Romanian and Spanish Hunters' Profile}

Due to the specific responses of the respondents in the study, we will present first the results for the profile of the hunter, comparatively for Romania and Spain in Table 2.

Table 2. The hunters profile.

\begin{tabular}{|c|c|c|c|c|}
\hline \multirow[b]{2}{*}{ Characteristics } & \multicolumn{2}{|c|}{ Absolute Frequencies } & \multicolumn{2}{|c|}{ Relative Frequencies } \\
\hline & $\begin{array}{c}\text { Romania } \\
(n=158)\end{array}$ & $\begin{array}{c}\text { Spain } \\
(n=140)\end{array}$ & $\begin{array}{c}\text { Romania } \\
(n=158)\end{array}$ & $\begin{array}{l}\text { Spain } \\
(n=140)\end{array}$ \\
\hline \multicolumn{5}{|l|}{ The hunting places } \\
\hline In my own country & 139 & 95 & $88 \%$ & $68 \%$ \\
\hline Abroad & 1 & 10 & $1 \%$ & $7 \%$ \\
\hline Both & 18 & 35 & $11 \%$ & $25 \%$ \\
\hline \multicolumn{5}{|l|}{ Type of hunting } \\
\hline Small game & 21 & 15 & $13 \%$ & $11 \%$ \\
\hline Big game & 27 & 24 & $17 \%$ & $17 \%$ \\
\hline Both & 110 & 101 & $70 \%$ & $72 \%$ \\
\hline \multicolumn{5}{|l|}{ Number of hunting days/year } \\
\hline$<10$ days & 8 & 5 & $5 \%$ & $4 \%$ \\
\hline 11-49 days & 63 & 48 & $40 \%$ & $34 \%$ \\
\hline 50-100 days & 43 & 49 & $27 \%$ & $35 \%$ \\
\hline 101-200 days & 11 & 9 & $7 \%$ & $6 \%$ \\
\hline$>200$ days & 33 & 29 & $21 \%$ & $21 \%$ \\
\hline \multicolumn{5}{|c|}{ The annual budget allocated for hunting } \\
\hline EUR < 1500 & 96 & 60 & $61 \%$ & $35 \%$ \\
\hline EUR 1501-3000 & 44 & 45 & $28 \%$ & $32 \%$ \\
\hline EUR > 3000 & 18 & 35 & $11 \%$ & $25 \%$ \\
\hline \multicolumn{5}{|c|}{$\begin{array}{l}\text { Visiting the tourist objectives and the } \\
\text { surroundings in the hunting' area }\end{array}$} \\
\hline Yes & 120 & 105 & $76 \%$ & $75 \%$ \\
\hline No & 38 & 35 & $24 \%$ & $25 \%$ \\
\hline
\end{tabular}

It can be seen (Table 2) that most Romanian hunters (88\%) act locally and a quarter of the Spanish respondents hunt both locally and abroad. The percentages of the type of hunting could be considered quite similar for Romania and Spain. For the number of hunting days/year, differences could be observed only for a medium time: 11-49 days and 50-100 days per year. We have to observe the different structures of the annual budget for hunting: 61\% of Romanian hunters expends under EUR 1500 and 57\% of Spanish hunters more than this amount.

Regarding trophy hunting, the distribution is presented in Figure 3.

We can observe that the Romanian respondents are big game trophy hunters and the Spanish respondents are smaller game trophy hunters.

\subsection{The Results for Hunting Data}

We will analyze the first two questions in this section of the questionnaire together due to the close connection between the importance of hunting in the life of each respondent and the fact that most of the time they think about it before sleeping (Figure 4). 


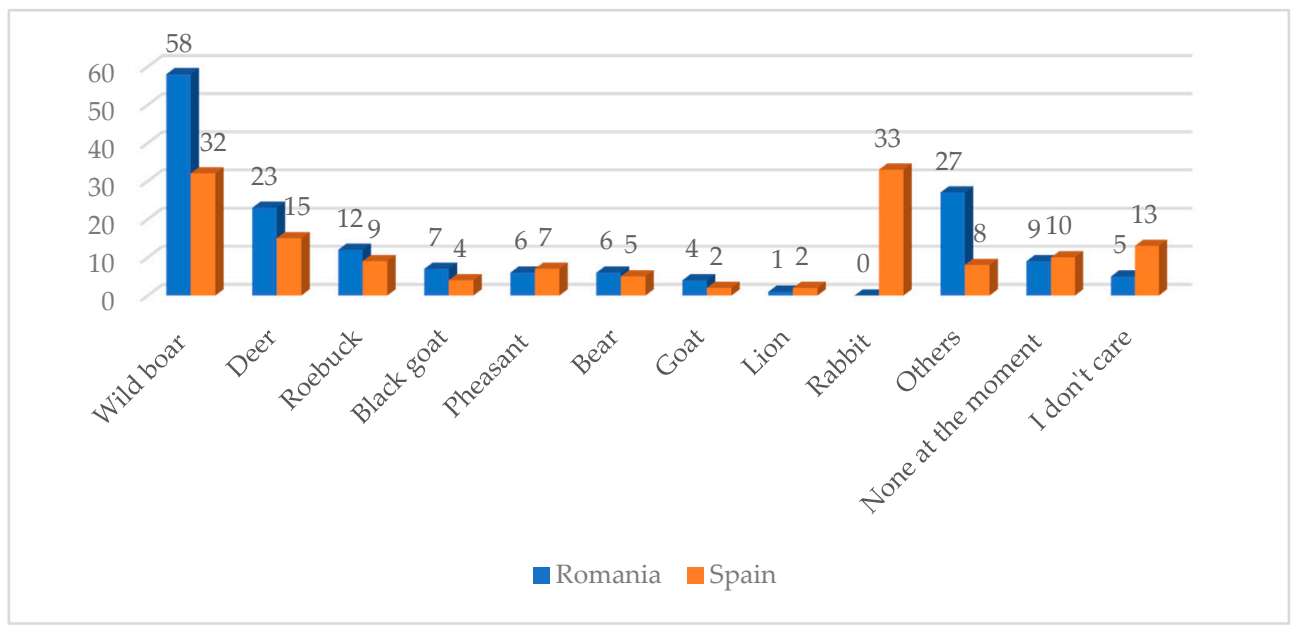

Figure 3. Trophy hunting.

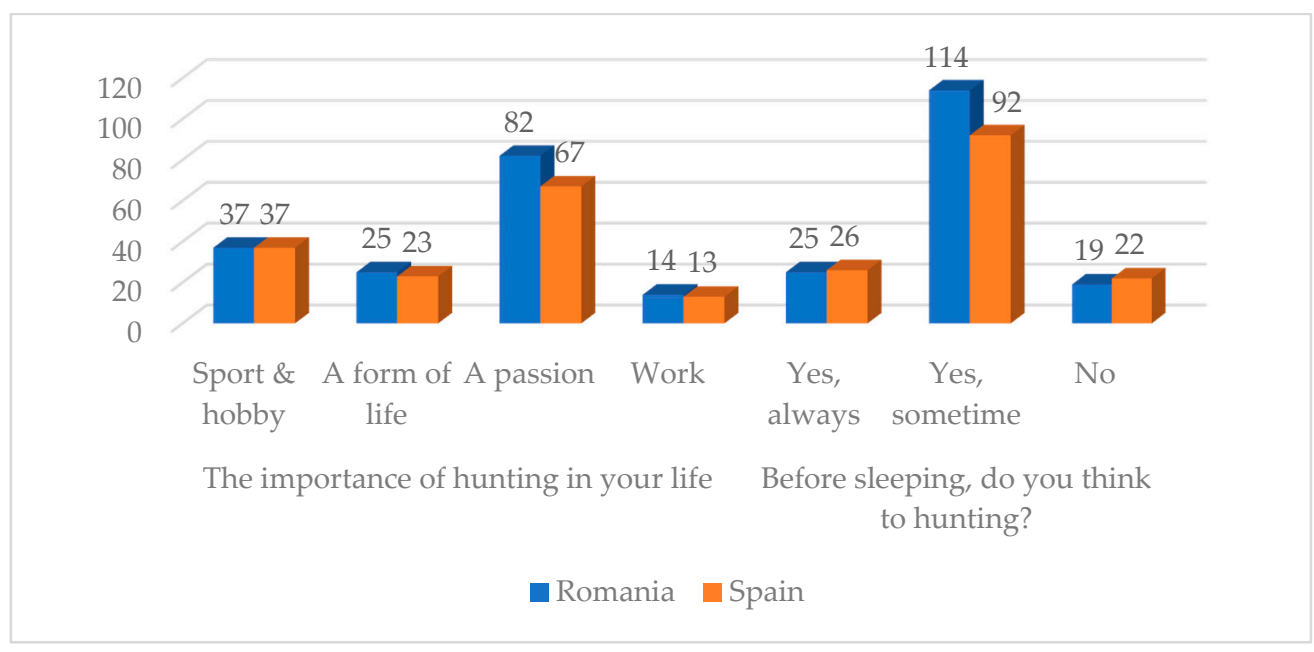

Figure 4. Distribution of the answers for two questions regarding the hunting data.

The distribution and structure of the Romanian and Spanish hunters together with the questions can be observed comparatively in Table 3.

\subsection{The Position of Hunters in Society and the Values of Hunting as Activity}

The first question of this part of the research refers to what hunters think that could be the current opinion of society about hunting. Therefore, 84 Romanian hunters (53\%) and 74 Spanish hunters (53\%) perceived a negative reaction of society regarding hunting; 62 Romanian hunters (39\%) and 56 Spanish hunters (40\%) think that this could depend on which economic sector represents the company; only 12 Romanian hunters $(8 \%)$ and 10 Spanish hunters $(7 \%)$ perceived a positive reaction of society regarding the hunting activities.

The perceptions of Romanian hunters regarding who or what could damage or harm the hunting, the hierarchy of the answers are: $54 \%$ - persons who do not know what hunting means, $14 \%$-hunters without ethical code, $12 \%$-local administration and politicians, $9 \%$ - persons without any respect for nature, $5 \%$-the ecologists, $5 \%$-the technology, $1 \%$-the communication tools. The structure of the Spanish hunters for the same question is: $59 \%$ - persons who do not know what hunting means, $11 \%$ each for: hunters without ethical code and persons without any respect for nature, $9 \%$-local administration and politicians, $6 \%$-the technology, $4 \%$-the ecologists, $1 \%$-the communication tools. 
Table 3. The distribution and structure of answers for other hunting data.

\begin{tabular}{|c|c|c|c|c|}
\hline \multirow[b]{2}{*}{ Characteristics/Questions and Answers } & \multicolumn{2}{|c|}{ Absolute Frequencies } & \multicolumn{2}{|c|}{ Relative Frequencies } \\
\hline & $\begin{array}{l}\text { Romania } \\
(n=158)\end{array}$ & $\begin{array}{c}\text { Spain } \\
(n=140)\end{array}$ & $\begin{array}{l}\text { Romania } \\
(n=158)\end{array}$ & $\begin{array}{c}\text { Spain } \\
(n=140)\end{array}$ \\
\hline \multicolumn{5}{|l|}{ The word that would describe you as a hunter, could be: } \\
\hline Person who loves animals & 44 & 48 & $28 \%$ & $34 \%$ \\
\hline Person who respects ethics and traditions & 55 & 43 & $35 \%$ & $31 \%$ \\
\hline Responsible and cautious person & 26 & 22 & $16 \%$ & $16 \%$ \\
\hline Sport person & 1 & 0 & $1 \%$ & $0 \%$ \\
\hline Passionate person & 30 & 25 & $19 \%$ & $18 \%$ \\
\hline Disappointed person & 2 & 2 & $1 \%$ & $1 \%$ \\
\hline \multicolumn{5}{|l|}{ The special hunting moment maybe considered: } \\
\hline Hunting itself & 36 & 43 & $23 \%$ & $31 \%$ \\
\hline The trophy & 0 & 0 & $0 \%$ & $0 \%$ \\
\hline Emotional and sentimental value & 56 & 44 & $35 \%$ & $31 \%$ \\
\hline The tradition and ethics of hunting & 66 & 53 & $42 \%$ & $38 \%$ \\
\hline \multicolumn{5}{|l|}{ The greatest hunting aspiration might be } \\
\hline To continue to practice hunting & 25 & 31 & $16 \%$ & $22 \%$ \\
\hline $\begin{array}{l}\text { To maintain the values of hunting (emotions, feelings, } \\
\text { ethics, and traditions) }\end{array}$ & 131 & 107 & $83 \%$ & $76 \%$ \\
\hline No aspirations & 1 & 1 & $1 \%$ & $1 \%$ \\
\hline To make a living from hunting & 1 & 1 & $1 \%$ & $1 \%$ \\
\hline To kill, the trophy, the quantitative & 0 & 0 & $0 \%$ & $0 \%$ \\
\hline
\end{tabular}

Source: own calculations.

Regarding the message of hunters might be for the persons against hunting, the structure of the answers are:

- For the Romanian hunters: 52\%—I would invite them to learn about hunting, $40 \%$-Only have an opinion if they know what hunting is, 5\%-Nothing, 3\%-To have respect for hunters.

- For the Spanish hunters: 56\%-I would invite them to learn about hunting, 36\%-Only have an opinion if they know what hunting is, $4 \%$-Nothing, $4 \%$-To have respect for hunters.

The values of hunting are presented, comparatively, in Figure 5. Regarding what they would like to disappear from the world of hunting, the hierarchy of the answers is the same for Romanian and Spanish sampling: 61\% for Romania, respectively, 64\% for Spain opted for poor hunting and administrative management followed by hunters without ethics ( $25 \%$ for Romania and 19\% for Spain), $8 \%$ for Romania and $11 \%$ for Spain opted for mischievous hunting, about $5 \%$ for improper weapons, only $1 \%$ for Romania and zero opted for trophy collectors.

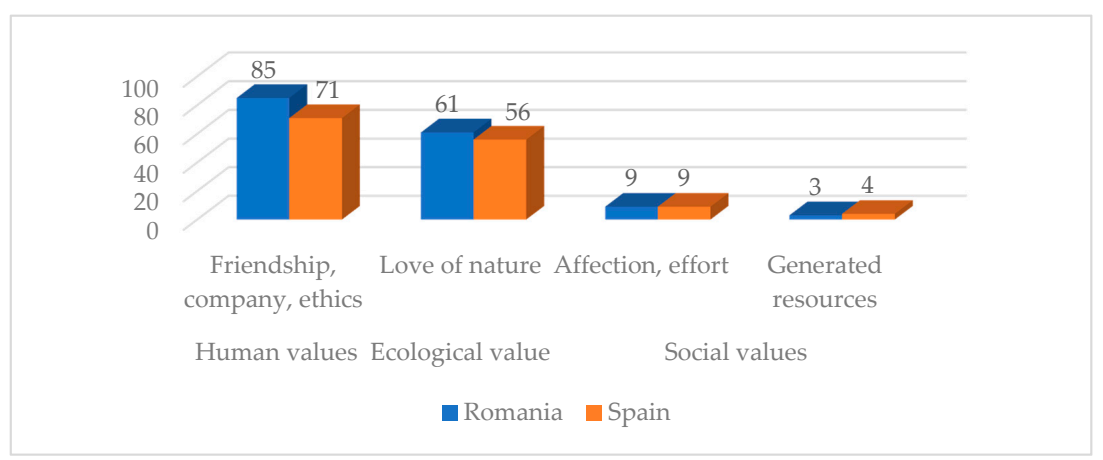

Figure 5. Hunting values. 
For the aspects regarding the improvements proposed by the hunters, the structures of answers are presented in Figure 6 for the Romanian hunters and Figure 7 for the Spanish hunters.

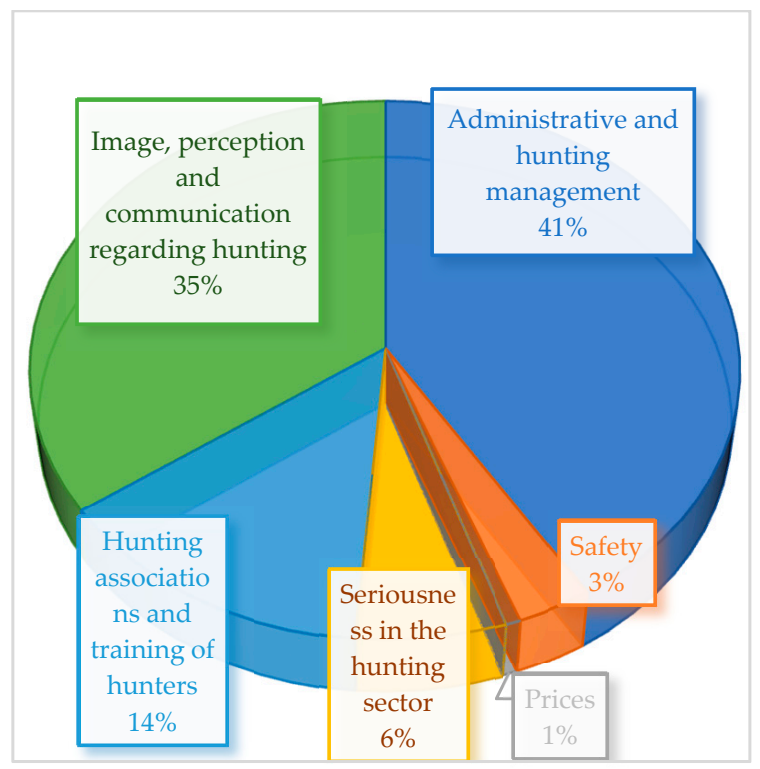

Figure 6. Romania.

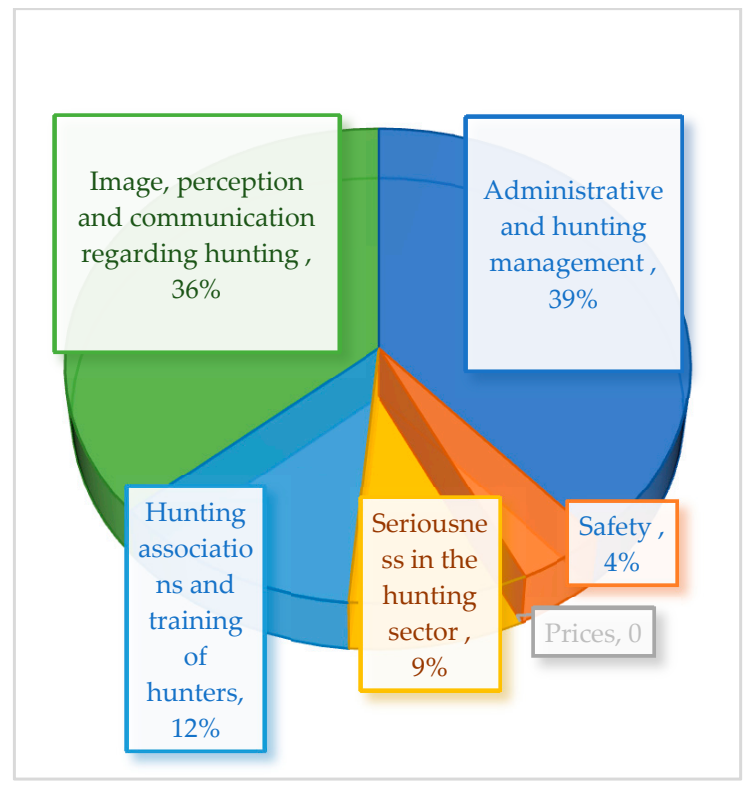

Figure 7. Spain.

The respondents were asked to answer other important aspects of hunting from their own perspectives: What obligations would you impose on hunting? The distribution of the answers was as follow:

- For the Romanian hunters: 59\%-Maximum compliance with hunting rules, 26\%-Training on environmental protection and security, $8 \%$-Respecting the environment, $5 \%$-Blood alcohol control, $3 \%$-none, $0 \%$-payment of the taxes.

- For the Spanish hunters: 54\%-Maximum compliance with hunting rules, 29\%-Training on environmental protection and security, $11 \%$-Respecting the environment, $6 \%$-Blood alcohol control, $1 \%$-none, $0 \%$ - payment of the taxes. 
The last questions of the research refer to the future direction for hunting in the Romanian and Spanish hunters' opinions showing that 33\% for Romania and 31\% for Spain hope for a traditional hunting adapted to the present, $28 \%$ for Romania and 32\% for Spain believe in an uncertain future for hunting, $23 \%$ for Romania and $21 \%$ for Spain think that hunting will be only a business, $5 \%$ from each country think that hunting will disappear in the future, only $3 \%$, respectively, $2 \%$ of hunters think hunting has a future in their country of origin.

3.4. The Statistical Analysis of the Relation between Hunters' Profiles, Hunting Data and the Position of Hunters in Society and the Values of Hunting as Activity

To analyze if there are correlations between different research variables, we applied the SPSS 23.0 software (Spearman correlations) due to the categorical data of the research. Only the statistically significant results were retained. The results for Romania are presented in Table 4 and show that:

- This is a positive correlation of low intensity $(0.237)$, statistically significant $(p$-value $=0.003)$ between variables "Before sleeping, do you think to hunting?" and "Visiting the tourist objectives and the surroundings the hunting' area". This correlation could indicate that those hunters who intensively think about hunting also visit the touristic objectives and the surrounding of the hunting area.

- There is a low-intensity negative, statistically significant $(p$-value $=0.000)$ correlation $(-0.314)$ between variables occupational status and the annual budget allocated for hunting. These results could also indicate that the young Romanian hunters allocate a larger budget for hunting than older ones.

Table 4. Correlation coefficients for Romania.

\begin{tabular}{|c|c|c|c|c|c|}
\hline & & $\begin{array}{c}\text { Before } \\
\text { Sleeping, Do } \\
\text { You Think to } \\
\text { Hunting? }\end{array}$ & $\begin{array}{l}\text { Occupational } \\
\text { Status }\end{array}$ & $\begin{array}{l}\text { The Annual } \\
\text { Budget Allocated } \\
\text { for Hunting }\end{array}$ & $\begin{array}{l}\text { Visiting the Tourist } \\
\text { Objectives and the } \\
\text { Surroundings the } \\
\text { Hunting Area }\end{array}$ \\
\hline \multirow{3}{*}{$\begin{array}{l}\text { Before sleeping, do } \\
\text { you think to hunting? }\end{array}$} & $\begin{array}{l}\text { Correlation } \\
\text { coefficient }\end{array}$ & 1.000 & 0.070 & -0.071 & $0.237 * *$ \\
\hline & Sig. (2-tailed) & & 0.383 & 0.378 & 0.003 \\
\hline & $\mathrm{N}$ & 158 & 158 & 158 & 158 \\
\hline \multirow[t]{3}{*}{ Occupational status } & $\begin{array}{l}\text { Correlation } \\
\text { coefficient }\end{array}$ & & 1.000 & $-0.314^{* *}$ & 0.013 \\
\hline & Sig. (2-tailed) & & & 0.000 & 0.867 \\
\hline & $\mathrm{N}$ & & 158 & 158 & 158 \\
\hline \multirow{3}{*}{$\begin{array}{l}\text { The annual budget } \\
\text { allocated for hunting }\end{array}$} & $\begin{array}{l}\text { Correlation } \\
\text { coefficient }\end{array}$ & & & 1.000 & -0.103 \\
\hline & Sig. (2-tailed) & & & & 0.197 \\
\hline & $\mathrm{N}$ & & & 158 & 158 \\
\hline \multirow{2}{*}{$\begin{array}{l}\text { Visiting the tourist } \\
\text { objectives and the } \\
\text { surroundings the } \\
\text { hunting area }\end{array}$} & $\begin{array}{l}\text { Correlation } \\
\text { coefficient } \\
\text { Sig. (2-tailed) }\end{array}$ & & & & 1.000 \\
\hline & $\mathrm{N}$ & & & & 158 \\
\hline
\end{tabular}

(Note: ${ }^{* *}$ significant statistically for $p$-value $<0.05$ ); Source: own calculations.

The results for Spain are presented in Table 5, and show that:

- $\quad$ There is a low to medium-intensity $(0.332)$, statistically significant $(p$-value $=0.000)$ positive correlation between variables occupational status and the importance of hunting in life. This correlation may indicate that for those Spanish hunters who are retired person, unemployed, or employed with secondary education, hunting represents a passion, a form of life, or even the workplace.

- There is a low intensity $(-0.226)$ statistically significant $(p$-value $=0.007)$ negative correlation between variables the importance of hunting in life and what the Spanish 
hunters want to disappear from the world of hunting. These results could indicate that those Spanish hunters who work as hunters or hunting represent a passion consider that mischievous hunting and inappropriate weapons must disappear from the hunting world.

Table 5. Correlation coefficients for Spain.

\begin{tabular}{|c|c|c|c|c|}
\hline & & $\begin{array}{l}\text { How Important Is } \\
\text { Hunting in Your Life? }\end{array}$ & $\begin{array}{l}\text { What Would You Do } \\
\text { to Disappear from the } \\
\text { World of Hunting? }\end{array}$ & $\begin{array}{c}\text { Occupational } \\
\text { Status }\end{array}$ \\
\hline \multirow{3}{*}{$\begin{array}{l}\text { How important is } \\
\text { hunting in your life? }\end{array}$} & Correlation coefficient & 1.000 & -226 & $0.332 * *$ \\
\hline & Sig. (2-tailed) & & 0.007 & 0.000 \\
\hline & $\mathrm{N}$ & 140 & 140 & 140 \\
\hline \multirow{3}{*}{$\begin{array}{l}\text { What would you do to } \\
\text { disappear from the } \\
\text { world of hunting? }\end{array}$} & Correlation coefficient & & 1.000 & -0.051 \\
\hline & Sig. (2-tailed) & & & 0.552 \\
\hline & $\mathrm{N}$ & & 140 & 140 \\
\hline \multirow{3}{*}{ Occupational status } & Correlation coefficient & & & 1.000 \\
\hline & Sig. (2-tailed) & & & \\
\hline & $\mathrm{N}^{\circ}$ & & & 140 \\
\hline
\end{tabular}

(Note: ${ }^{* *}$ significant statistically for $p$-value $<0.05$ ); Source: own calculations.

To test if there are statistically significant differences according to socio-demographic characteristics from Romania and Spain regarding the hunting data and hunters' opinions, we applied the chi-square bivariate test. The results of the first crosstab table are presented graphically in Figure 8.

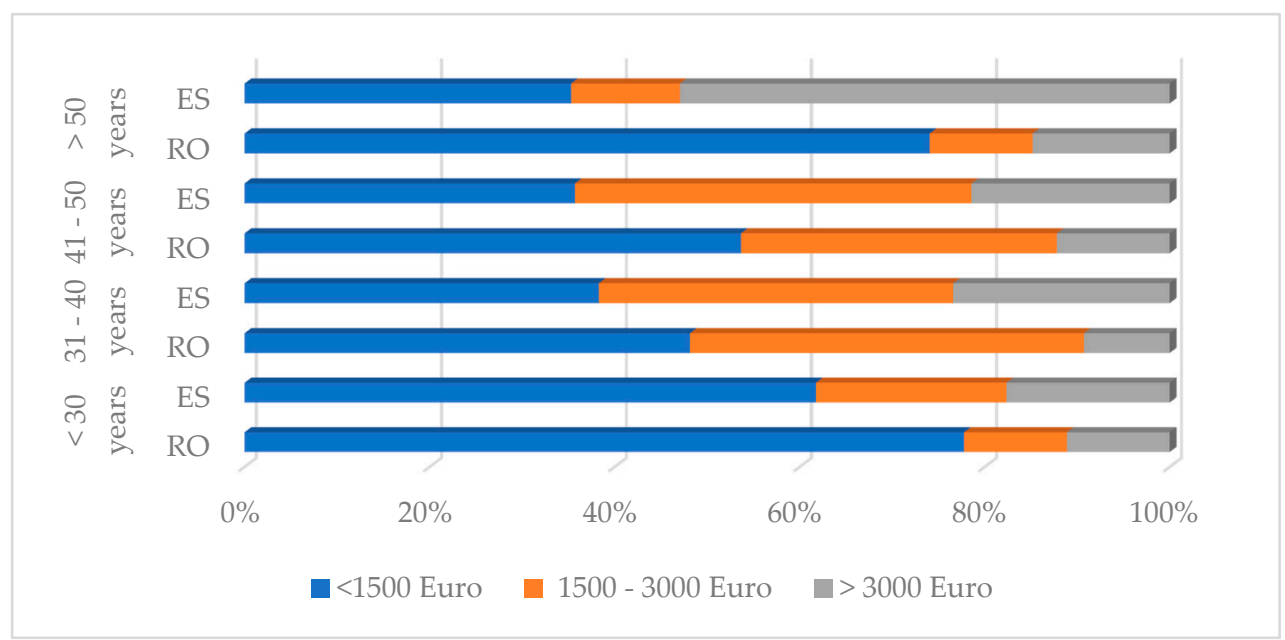

Figure 8. The distribution of hunters according to the age and annual budget for hunting.

The statistical results of the chi-square test are presented in Table 6, including the statistical hypotheses tested and test statistics $\left(\chi^{2}\right.$ calculated $=$ Pearson Chi-Square, $\mathrm{df}=$ degree of freedom, Asymp. Sig. (2-sided) $=p$-value).

For the first hypothesis from the above table, both values of $\chi^{2}$ calculated (for Romania $15.913<16.812$ and for Spain $15.760<16.812$ ) are smaller than the theoretical ones (from chi-square theoretical distribution table for six degrees of freedom and $p$-value $=0.01$ ) so, the hypotheses may be accepted and, in conclusions, there are no statistically significant differences according to the hunters' age regarding the annual allocated budget for hunting for both Romanian and Spanish hunters.

For the second hypothesis from Table 6, for Romania, the value of $\chi^{2}$ calculated is greater than $\chi^{2}$ theoretical $(25.705>25.188)$ so, we can reject the hypothesis for Romania and conclude that there are statistically significant differences according to the opinion 
of society regarding the hunting referring to future direction of the hunting from the hunters' perspective. For Spain, the value of $\chi^{2}$ calculated is smaller than $\chi^{2}$ theoretical $(22.314<23.209)$, therefore, we can accept the hypothesis, and, for Spain, there are no statistically significant differences according to the opinion of society regarding hunting referring to the future direction of hunting from the hunters' perspective.

The third hypothesis, the results from Table 6 , show that both values of $\chi^{2}$ calculated (for Romania $9.190<9.210$ and for Spain $13.538<13.816$ ) are smaller than the theoretical ones (from chi-square theoretical distribution table for 2 degrees of freedom and $p$-value $=0.01$ and 0.001 ) so, the hypotheses can be accepted and, in conclusion, for Romania and Spain, there are no statistically significant differences according to permanently thinking of hunting (even before sleeping) regarding the habit of visiting the touristic objectives and the surroundings of the hunting area.

Table 6. The results and statistical hypotheses for the chi-square test.

\begin{tabular}{llllllllll}
\hline$\chi^{2}$ Calculated & & df & & $\begin{array}{c}\text { Asymp. Sig. } \\
\text { (2-Sided) }\end{array}$ & $\chi^{2}$ Theoretical \\
\hline RO & ES & RO & ES & RO & ES & RO & ES \\
\hline
\end{tabular}

1. Hypothesis $H_{0}$ : There are no statistically significant differences according to the hunters' age regarding the annual allocated budget for hunting.

\begin{tabular}{lllllllll}
\hline Pearson chi-square & 15.913 & 15.760 & 6 & 6 & 0.014 & 0.015 & 16.812 & 16.812 \\
\hline
\end{tabular}

2. Hypothesis $H_{0}$ : There are no statistically significant differences according to opinion of society regarding the hunting referring to future direction of the hunting from the hunters' perspective.

\begin{tabular}{|c|c|c|c|c|c|c|c|c|}
\hline Pearson chi-square & 26.705 & 22.314 & 10 & 10 & 0.003 & 0.014 & 25.188 & 23.209 \\
\hline \multicolumn{9}{|c|}{$\begin{array}{l}\text { 3. Hypothesis } \mathrm{H}_{0} \text { : There are no statistically significant differences according to permanently thinking to } \\
\text { the hunting (even before sleeping) regarding the habit of visiting the touristic objectives and the } \\
\text { surroundings of the hunting area. }\end{array}$} \\
\hline Pearson chi-square & 9.190 & 13.538 & 2 & 2 & 0.010 & 0.001 & 9.210 & 13.816 \\
\hline \multicolumn{9}{|c|}{$\begin{array}{l}\text { 4. Hypothesis } H_{0} \text { : There are no statistically significant differences according to self-perception as hunter } \\
\text { regarding the most important values in the hunting world. }\end{array}$} \\
\hline Pearson chi-square & 35.710 & 49.705 & 15 & 12 & 0.002 & 0.000 & 35.628 & 32.209 \\
\hline
\end{tabular}

The last hypothesis tested from Table 6 shows that both for Romania and Spain, the values of $\chi^{2}$ calculated (for Romania $35.710>35.628$ and for Spain $49.705>32.909$ ) are greater than the theoretical ones (from chi-square theoretical distribution table for 15 respectively 12 degrees of freedom and $p$-value $=0.002$ respectively 0.000 ) so, the hypotheses must be rejected and, in conclusion, both for Romania and for Spain, there are statistically significant differences according to self-perception as a hunter regarding the most important values in the hunting world.

\section{Discussion}

Hunting is an activity with strong cultural roots that, in the 21st century, became a phenomenon with important social, economic, and spatial repercussions to become a real business [6]. Hunting tourism is a consequence of the changes that the practice of this ancestral activity has experienced over the centuries, as well as the increase in globalization, in which many activities are involved, including tourism. The progress that has taken place in terms of the means of transport, accessibility of territory, and a greater disposition of leisure and income have influenced the increase in the number of hunters over the years.

Nowadays, with the domination of the competitive market economy, in more and more countries, hunting is considered a distinct economic sector in the entire national economy, defined by object, subject, purpose, and method. An important contribution is also the emergence and development of companies specializing in hunting, whose clients are acquired through monographic fairs, through the internet, and/or hunting magazines. 
According to these aspects, the present results offer important solutions, especially for Romania, to develop as a hunting destination by offering specific elements of the hunting tourism product [45].

Hunting is a renewable natural resource, of national and international interest, which is administered and managed to conserve wildlife biodiversity, maintain ecological balance, practice hunting, and meet other economic and social requirements. Furthermore, residents have a slightly positive attitude towards hunting when it is for tourism and economic purpose [14].

Most of the research results from the international literature are based on qualitative analysis, as follows:

- Focus group discussions with stakeholders and local households [19] or local communities $[15,55]$;

- ethnographic interviews with business operators $[6,61]$;

- community perspectives of empowerment from trophy hunting tourism [21];

- semi-structured interviews with community members by applying the empowerment theory to trophy hunting tourism [21], the Community-based natural resource management [56] or key stakeholders [13];

- interviews with a small number of Swedish hunters regarding the human-nonhuman animal relationship [50].

Our research results fill a gap in the international literature, being the first comparative quantitative analysis on Romanian and Spanish hunters. In the international literature, we identified only one comparative study, Finland and the USA, but using an auto-ethnographic study [61]. Moreover, the present study is one of the few to investigate hunters as tourists [62].

The Romanian and Spanish hunters from the samples self-identified as individuals who respect ethics and traditions, are animals' lovers, and are responsible and cautious; therefore, these results validate the sin of neutralization of eco-guilt [63] but are practically the first step to the precautionary principle in hunting tourism planning [63]. Regarding the specific tourism activities linked to the hunting activities, $76 \%$ of Romanian hunters and $75 \%$ of Spanish hunters declare the visiting of tourism objectives and the surrounding in the hunting area and these results validates the results of Martin-Delgado et al. [44] referring to the Spanish hunters in the protected area of Extremadura region [44].

Our results regarding what hunters think in the current opinion of society about hunting mostly validate the ambivalence of hunting among Finnish hunters [52].

Our results regarding the overall satisfaction and the special moment of hunting invalidate the results of Matejevic et al. [46], respectively, for Romanian and Spanish hunters; hunting is for emotions and sentimental values along with the traditions and ethics of hunting contrary to trophy value of game and "to shoot game" and the "opportunity to see" from a Serbian study [46].

For the present results, considering the research objectives regarding the values of hunting for Romanian and Spanish hunters, their opinion for future of hunting, and the opinion of current society about hunting, we can conclude that we validate, for Romania comparatively with Spain, the most important principles of hunting tourism [2]:

- The principle of biodiversity preservation in the animal and plant life of hunting grounds;

- the principle of ecologically sustainable balanced use of hunting resources for tourism purposes;

- the principle of observance of ethical norms and national traditions in the process of organizing hunting tourism;

- the principle of preservation of the cultural heritage in the areas, which are reserved for the organization of hunting tourism;

- the principle of promoting the development of alternative types of hunting tourism;

- the principle of integrating hunting tourism with hunting, forestry, and agrarian enterprises; 
- the principle of state support in the development of hunting tourism.

Our results may have implications for the management of hunting tourism and trophy hunting both in Romania and Spain and offer a core result for similar regions that deserve further investigation and that complete the moral arguments concerning wildlife management and human well-being embedded in market relations and discourses on experiences [6] or to build a hunting tourism brand to achieve competitive advantages on the tourism market [42]. Moreover, the motivations of Romanian and Spanish hunters from the samples differentiate between regular hunters and hunting tourists [3] and it is still considered a traditional activity [49] providing cultural value from this activity [9]. From the economic perspective, according to FACE $[64,65]$, rural areas need hunting as an additional driving economic factor.

\section{Conclusions}

In conclusion, regarding the research objectives, the validation of research results from important worldwide studies demonstrates and confirms that among the values that identify hunting as an activity, Romanian and Spanish hunters highlight human values (friendship, company, ethics), ecological values (love of nature associated with hunting as a tool to understand and enjoy the natural environment), and social values (resources generated, hobby, effort). In addition, our respondents have the ability to self-criticize some components and aspects of hunting groups such as: hunters without ethical code (14\% for Romanian hunters and $11 \%$ for the Spanish one), local administration and politicians (12\% for Romania and $11 \%$ for Spain), persons with no respect for nature (9\% for Romania and $11 \%$ for Spain). In general, most participants consider that society has a negative perception of hunting. Although, it is appropriate to make a clear distinction between the perception they experience from society regarding hunting tradition, associated with the rural environment, and those who do and do not know this tradition.

Regarding the development of hunting in general, and trophy hunting worldwide, particularly in Romania and in Spain, hunters believe that the future of this sector is moving towards commercial hunting, associated with purchasing power to ensure results. Even if the density of hunters is different across both countries, Romania and Spain being at opposite ends according to the data in Figure 1, Romania is in last place in Europe in 2017 with 60,000 hunters and Spain is in second place with 980,000 hunters, regardless of the nationality of the hunters, their values related to this sector are similar.

Based on the literature review and the present research results, we can conclude that there is a need for greater use of hunters as part of the tourism sector, better management of hunters pursuing quality at the expense of quantity. The role of hunters in environmental conservation is irreplaceable and the fact that the opinions of the Romanian and Spanish respondents are almost similar highlights the importance of mentioning the tradition in the rural area, the ethics of hunting activities in protected areas, and maintaining the values of hunting: emotions, feelings, ethics, and traditions (83\% for Romanian hunters and $76 \%$ for Spanish hunters). Therefore, it is necessary to continue and strengthen agreements with conservation groups [66], with private entities that direct hunting tourists, so that society realizes that this activity does not harm the natural environment or the fauna that lives in it, but only favors it in terms of duration in time.

Our research has important theoretical and practical contributions to the existing literature, filling a gap in the international literature (especially for Europe) and being the first comparative quantitative analysis for two relatively different European countries, Romania and Spain. With these results, we demonstrated that Romania and Spain have an opposite position in Figure 1 regarding the numbers of hunters or different positions and preferences regarding trophy hunting. Overall, the values, opinions, and perceptions of Romanian and Spanish hunters are very similar.

The limits of the present research are linked to: 
- The relatively low number of respondents (158 for Romania and 140 for Spain) comparatively with the number of hunters for both countries but especially for Spain (980,000 hunters in Spain in 2017 and 60,000 for Romania:

- the representativeness of the Romanian and Spanish hunters in the sampling;

- the sampling methods-a non-probabilistic method (convenience sampling) using an online questionnaire;

- the time of data collection, respectively, during the COVID-19 pandemic (April-May 2021) with many travel restrictions in both countries.

For future research, to deepen the analysis, we intend to develop the questionnaire with the following aspects: touristic areas visited, accommodation structures used, and the reasons for choosing the tourist area visited on a larger sample.

Author Contributions: F.D.O. and M.R.G. contributed equally for this article. All authors have read and agreed to the published version of the manuscript.

Funding: This research was funded by the "George Emil Palade" University of Medicine, Pharmacy, Sciences and Technology of Târgu Mureș, contract research number 292/3.

Institutional Review Board Statement: Not applicable.

Informed Consent Statement: Not applicable.

Conflicts of Interest: The authors declare no conflict of interest.

\section{References}

1. Bredis, K.; Alvarez-Garcia, J.; De La Cruz Del Rio-Rama, M.; Coca Pérez, J.L. Analysis of hunting tourism research in scientific journals. Grand Tour 2015, 12, 94-105.

2. Hul, I.G.; Zavydivska, O.I.; Mandryk, V.O. Development of Hunting Tourism in Ukraine: Organizational, Economic and Legal Aspects. In Education Excellence and Innovation Management: A 2025 Vision to Sustain Economic Development during Global Challenges, Proceedings of the 35th International-Business-Information-Management-Association Conference (IBIMA), Seville, Spain, 1-2 April 2020; International Business Information Management Association, IBIMA: King of Prussia, PA, USA, 2020; pp. 960-971.

3. Suni, J.; Pesonen, J. Hunters as tourists—An exploratory study of push-pull motivations. Scand. J. Hosp. Tour. 2019, 19, 175-191. [CrossRef]

4. Tangeland, T.; Aas, O.; Odden, A. The Socio-Demographic Influence on Participation in Outdoor Recreation ActivitiesImplications for the Norwegian Domestic Market for Nature-Based Tourism. Scand. J. Hosp. Tour. 2013, 13, 190-207. [CrossRef]

5. Green, H. 'Game which the pampered pleasure seekers seek': Hunting tourism, conservation, and colonialism in the Yukon Territory, Canada, 1910-1940. J. Tour. Hist. 2021, 13, 138-164. [CrossRef]

6. Cederholm, E.A.; Sjöholm, C. The tourism business operator as a moral gatekeeper-The relational work of recreational hunting in Sweden. J. Sustain. Tour. 2021, 1-17. [CrossRef]

7. Reimoser, F.; Lexer, W.; Forstner, M.; Hackl, J.; Heckl, F. Criteria and indicators of sustainable hunting. Z. fur Jagdwiss. 2003, 49, 275-287.

8. Saayman, M.; van der Merwe, P.; Saayman, A. The economic impact of trophy hunting in the South African wildlife industry. Glob. Ecol. Conserv. 2018, 16, e00510. [CrossRef]

9. Willebrand, T. Promoting hunting tourism in north Sweden: Opinions of local hunters. Eur. J. Wildl. Res. 2008, 55, $209-216$. [CrossRef]

10. Saikim, F.H.; Prideaux, B.; Mohamed, M.; Hamzah, Z. Using Tourism as a Mechanism to Reduce Poaching and Hunting: A Case Study of the Tidong Community, Sabah; Book Series Advances in Hospitality and Leisure; Emerald Group Publishing Limited: Bingley, UK, 2016; Volume 12, pp. 119-144. [CrossRef]

11. Ruhanen, L.; Whitford, M. Cultural heritage and Indigenous tourism. J. Heritage Tour. 2019, 14, 179-191. [CrossRef]

12. Muñoz, L.; Hausner, V.; Brown, G.; Runge, C.; Fauchald, P. Identifying spatial overlap in the values of locals, domestic- and international tourists to protected areas. Tour. Manag. 2018, 71, 259-271. [CrossRef]

13. Watts, D.; Matilainen, A.; Kurki, S.P.; Keskinarkaus, S.; Hunter, C. Hunting cultures and the 'northern periphery': Exploring their relationship in Scotland and Finland. J. Rural. Stud. 2017, 54, 255-265. [CrossRef]

14. MacKay, K.J.; Campbell, J.M. An examination of residents' support for hunting as a tourism product. Tour. Manag. 2004, 25, 443-452. [CrossRef]

15. Dube, N. Voices from the village on trophy hunting in Hwange district, Zimbabwe. Ecol. Econ. 2019, 159, 335-343. [CrossRef]

16. Fischer, A.; Weldesemaet, Y.T.; Czajkowski, M.; Tadie, D.; Hanley, N. Trophy hunters' willingness to pay for wildlife conservation and community benefits. Conserv. Biol. 2015, 29, 1111-1121. [CrossRef] [PubMed]

17. McGranahan, D.A. Identifying ecological sustainability assessment factors for ecotourism and trophy hunting operations on private rangeland in Namibia. J. Sustain. Tour. 2011, 19, 115-131. [CrossRef] 
18. Baker, J.E. Development of a model system for touristic hunting revenue collection and allocation. Tour. Manag. 1997, 18, 273-286. [CrossRef]

19. Rashid, W.; Shi, J.; Rahim, I.U.; Dong, S.; Sultan, H. Issues and Opportunities Associated with Trophy Hunting and Tourism in Khunjerab National Park, Northern Pakistan. Animals 2020, 10, 597. [CrossRef]

20. Tolusic, Z. The effect of human resources on the development and enhancement of hunting in Croatia. In Interdisciplinary Management Research XIII Book Series: Interdisciplinary Management Research; Interdisziplinare Management Forschung; Gabler Verlag: Wiesbaden, Germany, 2017; Volume 13, pp. 535-547.

21. Thomsen, J.M.; Lendelvo, S.; Coe, K.; Rispel, M. Community perspectives of empowerment from trophy hunting tourism in Namibia's Bwabwata National Park. J. Sustain. Tour. 2021, 1-18. [CrossRef]

22. Mkono, M. Neo-colonialism and greed: Africans' views on trophy hunting in social media. J. Sustain. Tour. 2019, 27, 689-704. [CrossRef]

23. Koot, S. The Limits of Economic Benefits: Adding Social Affordances to the Analysis of Trophy Hunting of the Khwe and Ju/'hoansi in Namibian Community-Based Natural Resource Management. Soc. Nat. Resour. 2019, 32, 417-433. [CrossRef]

24. Mkono, M. The age of digital activism in tourism: Evaluating the legacy and limitations of the Cecil anti-trophy hunting movement. J. Sustain. Tour. 2018, 26, 1608-1624. [CrossRef]

25. Van der Merwe, P.; Saayman, M.; Rossouw, R. The economic impact of hunting: A regional approach. S. Afr. J. Econ. Manag. Sci. 2014, 17, 379-395. [CrossRef]

26. Humavindu, M.N.; Barnes, J.I. Trophy hunting in the Namibian economy: An assessment. S. Afr. J. Wildl. Res. 2003, 33, 65-70.

27. Wilkie, D.S.; Carpenter, J.F. The potential role of safari hunting as a source of revenue for protected areas in the Congo Basin. Oryx 1999, 33, 339-345. [CrossRef]

28. Sène-Harper, A.; Séye, M. Community-based Tourism around National Parks in Senegal: The Implications of Colonial Legacies in Current Management Policies. Tour. Plan. Dev. 2018, 16, 217-234. [CrossRef]

29. Angula, H.N.; Stuart-Hill, G.; Ward, D.; Matongo, G.; Diggle, R.W.; Naidoo, R. Local perceptions of trophy hunting on communal lands in Namibia. Biol. Conserv. 2018, 218, 26-31. [CrossRef]

30. Thiel, F. Hunting and Hunting Tourism in Namibia as a sustainable Development Factor. Erdkunde 2016, 70, 375-377.

31. Misakov, V.S.; Zherukova, A.B. Organizational, Ecological and Economic Aspects of Regional Hunting Tourism Development in Russian Federation. Helix 2019, 9, 4738-4743. [CrossRef]

32. Blackie, I. The impact of wildlife hunting prohibition on the rural livelihoods of local communities in Ngamiland and Chobe District Areas, Botswana. Cogent Soc. Sci. 2019, 5, 1558716. [CrossRef]

33. Naidoo, R.; Weaver, L.C.; Diggle, R.W.; Matongo, G.; Stuart-Hill, G.; Thouless, C. Complementary benefits of tourism and hunting to communal conservancies in Namibia. Conserv. Biol. 2016, 30, 628-638. [CrossRef]

34. Nordbø, I.; Turdumambetov, B.; Gulcan, B. Local opinions on trophy hunting in Kyrgyzstan. J. Sustain. Tour. 2017, 26, 68-84. [CrossRef]

35. Florin, T.I.; Tabita, A.; Cornelia, P.; Carmen, D.; Anda, M.; Iuliana, M.; Loredana, V.; Ioan, P. The role of hunting tourism in preserving the sustainability of fauna habitats. J. Biotechnol. 2018, 280, S47. [CrossRef]

36. Camara, G.; Munteanu, M.-V. Exploitation of hunting and fishing tourism in Galati county, Romania. Present Environ. Sustain. Dev. 2016, 10, 195-206. [CrossRef]

37. Prentovic, R.; Zivkovic, B.; Cvijanović, D. Hunting tourism in the function of rural development of Homolje. Èkon. Poljopr. 2016, 63, 71-87. [CrossRef]

38. Matilainen, A.; Keskinarkaus, S.; Törmä, H. The Economic Significance of Hunting Tourism in East Lapland, Finland. Hum. Dimens. Wildl. 2016, 21, 203-222. [CrossRef]

39. Calina, A.; Calina, J.; Milut, M.; Stan, I. Research on the practice of rural tourism specialized in sport and image hunting in Cergau area, Romania. Agrolife Sci. J. 2018, 7, 18-24.

40. Kalábová, M. Hunting Tourism as a Modern Product for the Development of Czech Regions. Hradec Econ. Days 2018, 8, 399-404. [CrossRef]

41. Kalabova, M.; Abrham, J. Hunting tourism as a sector with great potential for the development of Czech regions. In Proceedings of the 19th International Colloquium on Regional Sciences Location, Cejkovice, Czech, 15-17 June 2016; pp. 1073-1079. [CrossRef]

42. Milojica, V.; Drpic, D.; Nakovski, D. Developing hunting tourism-A new perspective of achieving competitiveness of rural Croatia. In Economy of Eastern Croatia Yesterday, Today, Tommorow; Josip Juraj Strossmayer University of Osijek, Faculty of Economics: Osijek, Croatia, 2014; Volume 3, pp. 107-121.

43. Martín-Delgado, L.-M.; Rengifo-Gallego, J.-I.; Sánchez-Martín, J.-M. Hunting in Extremadura—Profiles of the Hunter on the Basis of His Movements. Resources 2020, 9, 46. [CrossRef]

44. Martín-Delgado, L.-M.; Rengifo-Gallego, J.-I.; Sánchez-Martín, J.-M. Hunting Tourism as a Possible Development Tool in Protected Areas of Extremadura, Spain. Land 2020, 9, 86. [CrossRef]

45. Manojlovic, R.; Stamenkovic, I.; Gajic, T. Possibilities of more perspective development of the hunting destination "Karadordevo". Ekon. Poljopr. Econ. Agric. 2021, 68, 85-99. [CrossRef]

46. Matejevic, M.; Blesic, I.; Kalabova, M.; Ristic, Z.; Ponjiger, I.; Djeri, L. Differentiation of the attributes that influence tourist hunters' satisfaction in Serbia. Hum. Dimens. Wildl. 2021, 1-14. [CrossRef] 
47. Pichler, D. New property law regime of the hunting ground. Zbornik Pravnog Fakulteta Sveucilista U Rijeci 2019, 40, 481-500. [CrossRef]

48. Ruzic, D.; Banozic, M.; Tolusic, Z. Hunting tourism in Croatia-Possibilities and restrictions—Case study Vukovar-SRIJEM county. In Interdisciplinary Management Research XII Book Series: Interdisciplinary Management Research; Interdisziplinare Management Forschung; Gabler Verlag: Wiesbaden, Germany, 2016; Volume 12, pp. 349-362.

49. Pejnovic, D.; Krapinec, K.; Slamar, M. Hunters in Croatia as a socio-geographic group and their socio-demographic characteristics. Sumar. List 2010, 134, 461-474.

50. Norberg, J.; Engström, A.; Kjellén, V.; Carlsson, J. On the Hunt. Soc. Anim. 2017, 28, 233-251. [CrossRef]

51. Øian, H.; Skogen, K. Property and Possession: Hunting Tourism and the Morality of Landownership in Rural Norway. Soc. Nat. Resour. 2015, 29, 104-118. [CrossRef]

52. Nygård, M.; Uthardt, L. Opportunity or threat? Finnish hunters' attitudes to hunting tourism. J. Sustain. Tour. 2011, 19, 383-401. [CrossRef]

53. Störmer, N.; Weaver, L.C.; Stuart-Hill, G.; Diggle, R.W.; Naidoo, R. Investigating the effects of community-based conservation on attitudes towards wildlife in Namibia. Biol. Conserv. 2019, 233, 193-200. [CrossRef]

54. Samuelsson, E.; Stage, J. The size and distribution of the economic impacts of Namibian hunting tourism. S. Afr. J. Wildl. Res. 2007, 37, 41-52. [CrossRef]

55. Adom, D.; Boamah, D.A. Local attitudes toward the cultural seasonal hunting bans in Ghana's Bomfobiri Wildlife Sanctuary: Implications for sustainable wildlife management and tourism. Glob. Ecol. Conserv. 2020, 24, e01243. [CrossRef] [PubMed]

56. Stone, M.T.; Stone, L.S. Community-Based ecotourism and bushmeat consumption dynamics: Implications for conservation and community development. J. Sustain. Tour. 2020, 1-25. [CrossRef]

57. Mbaiwa, J.E. Effects of the safari hunting tourism ban on rural livelihoods and wildlife conservation in Northern Botswana. $S$. Afr. Geogr. J. 2017, 100, 41-61. [CrossRef]

58. Muboko, N.; Gandiwa, E.; Muposhi, V.K.; Tarakini, T. Illegal hunting and protected areas: Tourist perceptions on wild animal poisoning in Hwange National Park, Zimbabwe. Tour. Manag. 2016, 52, 170-172. [CrossRef]

59. Yitbarek, T.W.; Tadie, D.; Timer, G.; Fischer, A. Evaluating governance processes in the sharing of revenues from wildlife tourism and hunting in Ethiopia. Environ. Conserv. 2013, 40, 253-265. [CrossRef]

60. Gabor, M.R. Non-Probabilistic sampling use in qualitative marketing research. Haphazard sampling. Volunteer sampling. Ann. Univ. Oradea. Econ. Sci. 2007, 1, 955-959.

61. Komppula, R.; Gartner, W.C. Hunting as a travel experience: An auto-ethnographic study of hunting tourism in Finland and the USA. Tour. Manag. 2013, 35, 168-180. [CrossRef]

62. Komppula, R.; Suni, J. Identifying hunting tourist types-An exploratory case study from Finland. Tour. Rev. 2013, 68, 48-61. [CrossRef]

63. Tickle, L.; von Essen, E. The seven sins of hunting tourism. Ann. Tour. Res. 2020, 84, 102996. [CrossRef]

64. European Federation for Hunting and Conservation (FACE). Available online: https://www.face.eu/intergroup/ (accessed on 10 September 2021).

65. FACE. The Economic Value of Hunting in the EU. Available online: https://www.face.eu/sites/default/files/documents/ english/economia_della_caccia_27_9_2016_en.pdf (accessed on 10 September 2021).

66. Oltean, F.D.; Gabor, M.R. Hunting tourism-leisure, sustainable or trophy activtity? A comparative motivational study: Spain and Romania. In Book of Abstract Scientific Session of University Academic Staff, 7-11 December 2020; George Emil Palade University of Medicine, Pharmacy, Science, and Technology of Targu Mures, University Days University Press: Târgu Mureș, Romania; Volume 3, p. 50. 